\title{
“OPAK IMUT" DAN “OPAK MINI" SEBAGAI SOLUSI PENINGKATAN MUTU PRODUK CASSAVA CHIPS DI DESA SIDODADI KECAMATAN PONDOK KELAPA KABUPATEN BENGKULU TENGAH
}

\section{“OPAK IMUT" AND "OPAK MINI" AS SOLUTION OF CASSAVA CHIPS QUALITY IMPROVEMENT AT SIDODADI VILLAGE PONDOK KELAPA REGENCY CENTRAL BENGKULU DISTRICT}

\author{
Hesti Nur'aini ${ }^{1)}$, Karona Cahya Susena ${ }^{2)}$, Ahmad Soleh ${ }^{2)}$ \\ ${ }^{1)}$ Fakultas Pertanian Universitas Dehasen \\ ${ }^{2)}$ Fakultas Ekonomi Universitas Dehasen \\ Jln. Meranti Raya No. 32 Sawah Lebar Bengkulu 38228 \\ Email : hestinuraini1996@gmail.com
}

\begin{abstract}
ABSTRAK
Desa Sidodadi Kecamatan Pondok Kelapa Kabupaten Bengkulu Tengah merupakan salah satu desa yang mempunyai potensi cukup besar dalam pengembangan industri pengolahan pangan. Pada tahun 1990-an, jumlah industri rumah tangga di desa ini mencapai 25 industri, namun mulai tahun 2000 jumlah industri rumah tangga ini mengalami penurunan, dan saat ini hanya terdapat 5 industri rumah tangga pengolahan singkong. Tujuan kegiatan Pengabdian kepada Masyarakat ini adalah untuk meningkatkan ketrampilan, diversifikasi produk dan memperbaiki sistem pemasaran yang optimal. Hasil kegiatan menunjukkan bahwa diversifikasi dan modifikasi produk opak pada UD. Purwati dan UD. Sugiono memberikan dampak yang positif baik dari segi kualitas produk, tingkat penerimaan konsumen dan kapasitas produksi. Perbaikan desain kemasan juga bisa meningkatkan penerimaan konsumen, sehingga "Opak Imut" dan "Opak Mini" yang menjadi merk dagang opak produksi mitra bisa mencapai jaringan pemasaran yang lebih luas dan bisa dikonsumsi untuk skala anak-anak ataupun cemilan keluarga dan oleh-oleh.
\end{abstract}

Kata kunci : Desa Sidodadi, “cassava chips”, pengemasan, pemasaran

\section{ABSTRACT}

Sidodadi village Pondok Kelapa Regency District of Central Bengkulu is one of the villages that have a great potential in the development of food processing industry. In the 1990s, the number of households cassava processing industry in this country reached 25 industry, but in 2000 the number of domestic industry's decline, until now there are only 5 households cassava processing industry. The objective of this community service program is to improve the skills, diversification of cassava chips products and improve the marketing system. Results showed that the diversification of activities and modification of cassava chips products at UD. Purwati and UD. Sugiono have a positive impact in terms of product quality, the level of consumer acceptance and production capacity. Packaging 
design improvements to increase consumer acceptance, so that the "Opak Imut" and "Opak Mini" which became a trademark of cassava chips partners production could reach a wider marketing network and can be consumed by children or family snacks and souvenirs.

Keywords : Sidodadi Village, cassava chips, packaging, marketing

\section{PENDAHULUAN}

Dewasa ini pengelolaan industri kecil mendapatkan perhatian yang cukup serius dari pemerintah, baik tingkat pusat maupun provinsi. Di wilayah Provinsi Bengkulu, perkembangan industri kecil juga cukup pesat, khususnya industri pengolahan pangan. Desa Sidodadi Kecamatan Pondok Kelapa Kabupaten Bengkulu Tengah merupakan salah satu desa yang mempunyai potensi cukup besar dalam pengembangan industri pengolahan pangan. Salah satu industri kecil yang ada di Desa Sidodadi Kecamatan Pondok Kelapa Kabupaten Bengkulu Tengah adalah industri pengolahan singkong/ ubi kayu menjadi opak. Pada tahun 1990-an, jumlah industri rumah tangga di desa ini mencapai 25 industri, namun mulai tahun 2000 jumlah industri rumah tangga ini mengalami penurunan, dan saat ini hanya terdapat 5 industri rumah tangga pengolahan singkong (Profil Desa Sidodadi, 2014).

Lambatnya perkembangan industri pengolahan singkong di Desa Sidodadi ini disebabkan beberapa faktor antara lain kurangnya minat konsumen terhadap produk opak yang mulai terkalahkan dengan produk-produk pangan lain yang lebih modern. Hasil survei pendahuluan yang penulis lakukan menunjukkan bahwa produk opak yang dihasilkan beberapa industri di wilayah Desa Sidodadi masih bersifat monoton dari tahun ke tahun dengan penampilan dan rasa yang kurang menarik, tanpa dilakukan proses pengemasan yang memadai. Penjualan opak oleh industri hanya dilakukan pada produk mentah yang diikat dengan tali plastik yang berisi 30 lembar opak per ikatnya. Kondisi ini tentu saja tidak mengundang minat konsumen, selain tampilan dan higienitas yang kurang terjaga, konsumen juga masih harus menggoreng sendiri opak yang akan dikonsumsinya. Melihat permasalahan tersebut, penulis tertarik untuk membantu membenahi sistem produksi dan manajemen industri opak di Desa Sidodado dengan dilakukannya diversifikasi produk, kemasan serta sistem pemasaran produk yang dihasilkan. Dengan peningkatan kualitas, diversifikasi produk, teknologi kemasan 
serta sistem pemasaran yang tepat, produk ini akan menjadi lebih bernilai ekonomi tinggi dan layak untuk dikembangkan serta memungkinkan untuk dapat lebih menampung banyak tenaga kerja. Oleh karena itu, penulis bersama-sama mitra mengidentifikasi bahwa perlu dilakukannya peningkatan soft skill dan ketrampilan bagi para pengusaha pengolahan opak di Desa Sidodadi, yang bisa dilakukan melalui pendidikan, pelatihan dan aplikasi dalam program Pengabdian kepada Masyarakat. Data yang dihimpun oleh tim penulis menunjukkan bahwa saat ini hanya tinggal 5 industri kecil penghasil opak ubi kayu yang ada di Desa Sidodadi. Sebagai mitra kegiatan Pengabdian kepada Masyarakat, pengusul mengambil 2 industri, yaitu UD. Sugiono dan UD. Purwati, dengan pertimbangan selain lokasinya yang relatif mudah dijangkau, stabilitas produksi di kedua industri ini cukup memadai. Ditinjau dari aspek produksi dan sistem manajemennya, UD. Sugiono dan UD. Purwati mempunyai karakter yang relatif sama, dengan uraian seperti disajikan pada Tabel 1.

Tabel 1. Aspek Produksi Mitra

\begin{tabular}{|c|l|l|}
\hline No. & \multicolumn{1}{|c|}{ Kriteria } & \multicolumn{1}{c|}{ Keterangan } \\
\hline 1. & Produk yang diolah & $\begin{array}{l}\text { a. Opak dengan bumbu } \\
\text { b. Opak tanpa bumbu } \\
\text { c. Keripik singkong }\end{array}$ \\
\hline 2. & Kapasitas produksi opak & $\begin{array}{l}40-50 \text { ikat per hari } \\
\text { (30 lembar opak per ikat) }\end{array}$ \\
\hline 3. & Alat produksi & $\begin{array}{l}\text { a. Peralatan dapur } \\
\text { b. Ampia (pencetak mie) } \\
\text { c. Papan penjemur (para-para) }\end{array}$ \\
\hline 4. & Kemasan Produk & $\begin{array}{l}\text { Hanya diikat menggunakan tali plastik, } \\
\text { tanpa kemasan luar }\end{array}$ \\
\hline 5. & Pengelola & $\begin{array}{l}\text { Kepala rumah tangga sebagai pimpinan, } \\
\text { dibantu anggota keluarga lain dan 1 orang } \\
\text { karyawan lepas }\end{array}$ \\
\hline 6. & Pemasaran & $\begin{array}{l}\text { a. Dipajang/digantung di teras rumah } \\
\text { b. Dijual kepada penadah/distributor }\end{array}$ \\
\hline 7. & Harga jual & $\begin{array}{l}\text { Rp. 6.000,- per ikat (isi 30 lembar opak } \\
\text { dengan diameter } \pm \text { 10 cm per lembarnya) }\end{array}$ \\
\hline
\end{tabular}

Sumber : UD. Sugiono dan UD. Purwati (April 2014) 
Tujuan kegiatan Pengabdian kepada Masyarakat ini adalah untuk meningkatkan ketrampilan, diversifikasi produk dan memperbaiki sistem pemasaran yang optimal.

\section{METODE PELAKSANAAN}

Kegiatan utama yang dilakukan adalah perbaikan kualitas produk olahan “cassava chips" meliputi aspek bentuk, ukuran, tampilan, rasa dan kemasan yang dilanjutkan dengan perbaikan metode pemasaran, sehingga secara rinci tahapan kegiatan diklatnya meliputi :

1. Perbaikan teknologi pengolahan "cassava chips" dengan melakukan pengecilan ukuran dari ukuran diameter $13 \mathrm{~cm}$ menjadi $3 \mathrm{~cm}$ dan diversifikasi varian rasa (original, balado, jagung bakar dan barbeqiu).

2. Analisis uji sensoris untuk menentukan tingkat penerimaan konsumen terhadap produk "cassava chips" yang telah dikembangkan (Kartika, B, 2000).

3. Perancangan desain kemasan "cassava chips" yang sesuai dengan standar minimal kemasan produk pangan.

4. Perancangan metode pemasaran dengan nama merk dan kemasan yang menarik serta memasarkan dengan jaringan yang luas (Kottler, $\mathrm{P}$ dan Gery, A, 2013; Kottler, P dan Kevin, L.K, 2013).
5. Aplikasi teknologi dan evaluasi hasil aplikasi teknologi.

\section{HASIL KEGIATAN DAN PEMBAHASAN}

Perbaikan Teknologi Pengolahan "Cassava Chips"Berdasarkan hasil survei awal yang dilakukan oleh tim, teknologi pengolahan opak di UD Sugiono dan UD Purwati masih sangat sederhana, dengan rincian sebagai berikut

a. Bahan baku ubi kayu yang telah dikupas dikukus hingga masak, kemudian digiling menggunakan penggiling daging (meat grinder) ukuran kecil yang sederhana dan manual.

b. Hasil penggilingan ubi kayu tersebut selanjutnya diberi bumbu berupa garam dan bawang putih giling dan diaduk hingga merata.

c. Pencetakan dilakukan secara manual dengan cara menghamparkan adonan di atas alas plastik sambil ditekan dan diratakan hingga ketebalan kurang lebih $2 \mathrm{~mm}$, kemudian dicetak dengan bentuk bulat dengan diameter $12 \mathrm{~cm}$ menggunakan tutup toples.

d. Penjemuran dilakukan di atas parapara bambu yang telah dipasang di halaman rumah. 
e. Opak kering yang dihasilkan dijual dalam bentuk mentah (belum digoreng) dengan cara memajang ikatan opak (berisi 10 lembar per ikat) di depan rumah, menunggu konsumen atau penadah datang.

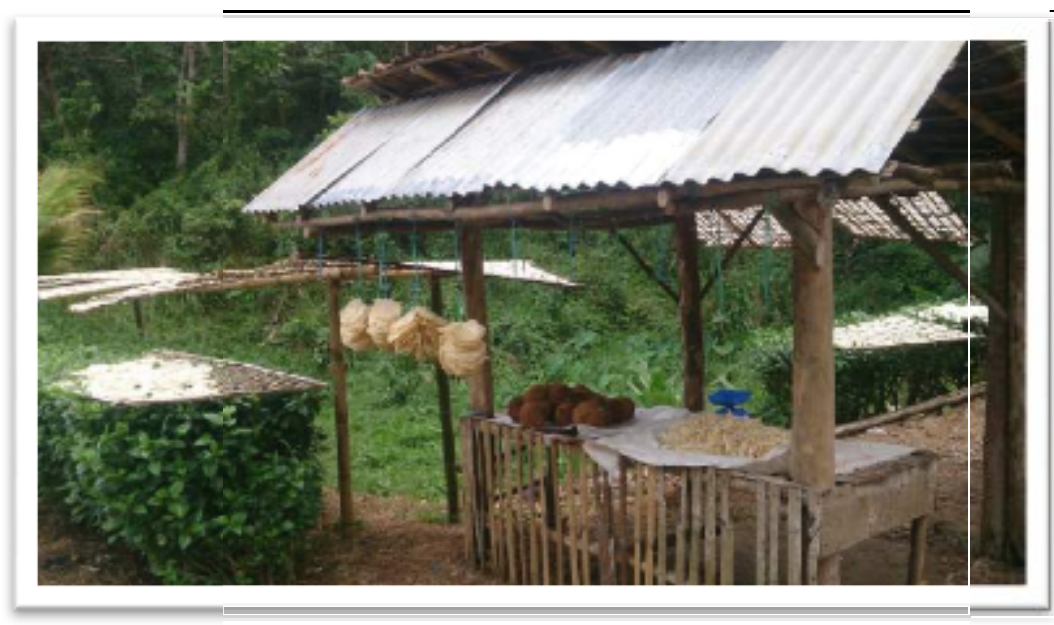

Gambar 1. Ilustrasi Produk dan Metode Pemasaran Opak Produksi Mitra Sebelum Modifikasi

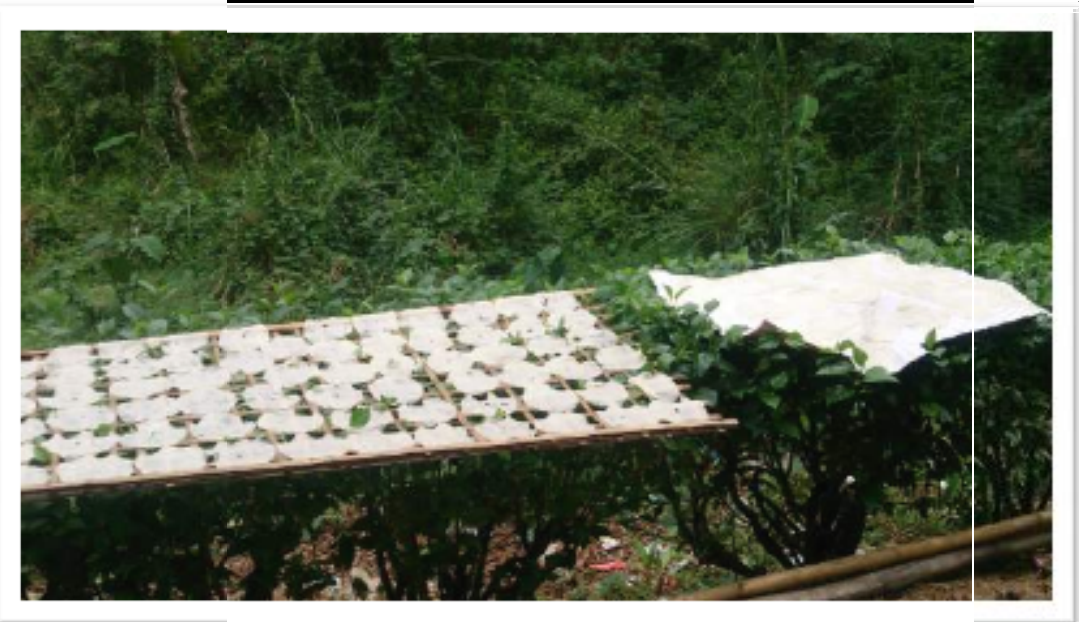

Gambar 2. Proses Pengeringan Opak di UD Purwati 
Dengan metode pengolahan yang sangat sederhana tersebut, tim beserta mitra menilai perlu dilakukan perbaikan teknologi pengolahan dan pengemasan, sehingga diperoleh efektivitas yang berujung pada peningkatan tingkat perekonomian mitra. Perbaikan teknologi yang dilakukan meliputi perubahan dan diversifikasi metode pengolahan opak, dengan rincian sebagai berikut :

a. Bahan baku ubi kayu yang telah dikupas dikukus hingga masak, kemudian digiling menggunakan penggiling daging elektrik dengan kapasitas yang lebih besar dan otomatis menggunakan energi listrik, yang disediakan oleh tim.

b. Hasil penggilingan ubi kayu tersebut selanjutnya diberi bumbu berupa garam dan diaduk hingga merata.

c. Pencetakan dilakukan dengan cara menghamparkan adonan di atas alas plastik sambil ditekan dan diratakan hingga ketebalan kurang lebih $2 \mathrm{~mm}$, kemudian dicetak dengan bentuk bulat dengan diameter $3 \mathrm{~cm}$.

d. Penjemuran dilakukan di atas parapara bambu.

a. Opak mini yang telah kering selanjutnya digoreng menggunakan minyak panas.

b. Setelah digoreng, dlakukan penirisan minyak menggunakan alat peniris minyak ("spinner") dengan kapasitas
1,5 kg opak untuk satu kali proses. Fungsi "spinner" ini adalah untuk meniriskan atau mengurangi kadar minyak di dalam produk sehingga produk menjadi kering dan mempunyai kualitas serta umur simpan yang lebih tinggi.

Sebelum dilakukan pengemasan, produk opak dicampur dengan tepung bumbu dengan 3 variasi rasa, yaitu netral, balado, jagung bakar dan barbeqiu.

\section{Analisis Tingkat Penerimaan Konsumen}

Analisis tingkat penerimaan konsumen dilakukan dengan melakukan uji sensoris terhadap produk opak sebelum dan sesudah dilakukan perbaikan teknologi. Uji sensoris merupakan cara pengujian dengan menggunakan indera manusia sebagai alat utama untuk pengukuran daya penerimaan terhadap produk. Pengujian organoleptik mempunyai peranan penting dalam penerapan mutu. Pengujian organoleptik dapat memberikan indikasi kebusukan, kemunduran mutu dan kerusakan lainnya dari produk (Soekarto, 2006). Dalam pelaksanaan uji sensoris opak, digunakan 20 orang panelis terlatih, yang terdiri dari mahasiswa Program Studi Teknologi Pertanian dan Teknologi Pangan Fakultas Pertanian Universitas Dehasen (Unived) Bengkulu. Pelaksanaan kegiatan uji 
sensoris dilakukan di Laboratorium Uji

Sensoris Fakultas Pertanian Unived.

Penilaian sensoris terdiri dari dua macam pengujian dengan rincian sebagai berikut

\section{Analisis Uji Perbandingan Opak}

Pengujian perbandingan kualitas produk opak sebelum dan sesudah dilakukan modifikasi, dilakukan dengan menggunakan metode uji pembanding untuk parameter kenampakan, rasa dan mutu keseluruhan, dengan hasil seperti disajikan pada Tabel 2.

Hasil pengujian menunjukkan bahwa panelis memberikan respon yang lebih baik terhadap produk opak hasil modifikasi dibandingkan opak sebelum dimodifikasi, khususnya untuk parameter kenampakan dan rasa, sementara untuk parameter tekstur, panelis menilai tidak ada perbedaan yang nyata pada produk opak sebelum dan sesudah modifikasi. Hal ini menunjukkan bahwa kualitas sensori produk opak dipengaruhi oleh bentuk penampilan dan rasanya. Kenyataan ini juga mendukung hipotesis bahwa modifikasi perubahan bentuk dan variasi rasa yang dilakukan pada produk opak hasil produksi UD. Purwati dan UD. Sugiono memberikan pengaruh yang positif terhadap tingkat penerimaan konsumen. Dengan demikian, harapan peningkatan nilai ekonomi produk opak yang dihasilkan oleh UD. Purwati dan UD. Sugiono bisa terlaksana.

\section{Analisis Tingkat Kesukaan Opak Hasil Modifikasi}

Pengujian tingkat kesukaan panelis terhadap produk opak hasil perbaikan teknologi, meliputi parameter kenampakan, rasa dan tekstur. Hasil analisis tingkat kesukaan panelis tersebut disajikan pada Tabel 3.

Pengujian sensoris (hedonic test) dilakukan untuk mengetahui bagaimana tingkat penerimaan konsumen terhadap produk baru atau produk hasil modifikasi. Pengujian ini dilakukan di laboratorium Fakultas Pertanian Universitas Dehasen dengan panelis terlatih yang terdiri dari mahasiswa Program Studi Teknologi Pertanian dan Teknologi Pangan. Hasil pengujian bisa dijadikan sebagai acuan tingkat penerimaan konsumen terhadap produk yang diujikan.

Hasil pengujian tingkat kesukaan panelis terhadap produk opak hasil modifikasi seperti disajikan pada Tabel 3 menunjukkan bahwa tingkat penerimaan panelis terhadap parameter kenampakan, rasa dan tekstur termasuk dalam rentang netral hingga sangat suka, dengan ratarata tingkat kesukaan tertinggi berada pada opak rasa balado dan jagung bakar, dan skala terendah pada rasa original (tanpa bumbu). Namun secara 
keseluruhan, tingkat penerimaan panelis terhadap opak hasil modifikasi ini termasuk dalam kategori baik, sehingga proses produksi produk opak hasil modifikasi ini layak untuk dilanjutkan. Tabel 4 menjelaskan perbandingan kualitas produk opak sebelum dan sesudah dilakukan perbaikan teknologi pengolahan, sementara tampilan produk disajikan pada Gambar 4 dan 5.

\section{Perancangan Desain Kemasan}

Pengemasan merupakan suatu cara atau perlakuan pengamanan terhadap makanan atau bahan pangan, agar makanan atau bahan pangan baik yang belum diolah maupun yang telah mengalami pengolahan, dapat sampai ke tangan konsumen dengan "selamat", secara kuantitas maupun kualitas. Selain sebagai pelindung, kemasan pangan juga bisa berfungsi sebagai sumber informasi, sarana promosi dan menambah daya tarik konsumen, (Robertson, 2013).

Tabel 2. Hasil Uji Sensoris Perbandingan Produk Opak Sebelum dan Sesudah Modifikasi

\begin{tabular}{|c|c|c|c|}
\hline Produk Opak & Kenampakan & Rasa & Keseluruhan \\
\hline Sebelum modifikasi & $2,70 \mathrm{a}$ & $3,20 \mathrm{a}$ & $3,60 \mathrm{a}$ \\
\hline Setelah modifikasi & $3,60 \mathrm{~b}$ & $3,90 \mathrm{~b}$ & $3,65 \mathrm{a}$ \\
\hline
\end{tabular}

Ket Skala : $5=$ sangat suka; $4=$ suka; $3=$ agak suka; 2 = tidak suka; $1=$ sangat tidak suka Notasi yang berbeda pada kolom yang sama menunjukkan beda nyata dengan taraf 5\%

Tabel 3. Hasil Uji Sensoris Tingkat Kesukaan Panelis terhadap Opak Hasil Modifikasi

\begin{tabular}{|l|c|c|c|}
\hline \multicolumn{1}{|c|}{ Varian Rasa } & Kenampakan & Rasa & Tekstur \\
\hline Balado & $4,05 \mathrm{a}$ & $4,35 \mathrm{a}$ & $4,15 \mathrm{a}$ \\
\hline Jagung bakar & $4,20 \mathrm{a}$ & $4,65 \mathrm{a}$ & $4,40 \mathrm{a}$ \\
\hline Barbeqiu & $3,80 \mathrm{a}$ & $3,80 \mathrm{~b}$ & $3,65 \mathrm{~b}$ \\
\hline Original & $3,20 \mathrm{~b}$ & $3,35 \mathrm{c}$ & $3,70 \mathrm{~b}$ \\
\hline
\end{tabular}

Ket Skala : $5=$ sangat suka; $4=$ suka; $3=$ agak suka; $2=$ tidak suka; $1=$ sangat tidak suka Notasi yang berbeda pada kolom yang sama menunjukkan beda nyata dengan taraf 5\% 
Tabel 4. Perbandingan Kualitas Produk Opak Sebelum dan Sesudah Dilakukan Perbaikan Teknologi Pengolahan

\begin{tabular}{|c|c|c|c|}
\hline No. & Parameter & Opak Teknologi Lama & Opak Teknologi Baru \\
\hline 1 & Tampilan produk & $\begin{array}{l}\text { - Ukuran lebar dan } \\
\text { kurang menarik } \\
\text { - Membutuhkan ruang } \\
\text { simpan yang luas }\end{array}$ & $\begin{array}{l}\text { - Ukuran kecil dan } \\
\text { lebih menarik } \\
\text { - Ruang penyimpanan } \\
\text { lebih praktis }\end{array}$ \\
\hline 2 & $\begin{array}{l}\text { Efektivitas } \\
\text { produksi }\end{array}$ & $\begin{array}{l}\text { Membutuhkan waktu } \\
\text { tenaga manual lebih } \\
\text { banyak }\end{array}$ & $\begin{array}{l}\text { Lebih hemat waktu dan } \\
\text { tenaga }\end{array}$ \\
\hline 3 & $\begin{array}{l}\text { Penerimaan } \\
\text { konsumen }\end{array}$ & $\begin{array}{l}\text { Penerimaan relatif } \\
\text { rendah }\end{array}$ & Lebih disukai panelis \\
\hline 4 & Variasi rasa & Tradisional & Lebih variatif \\
\hline
\end{tabular}

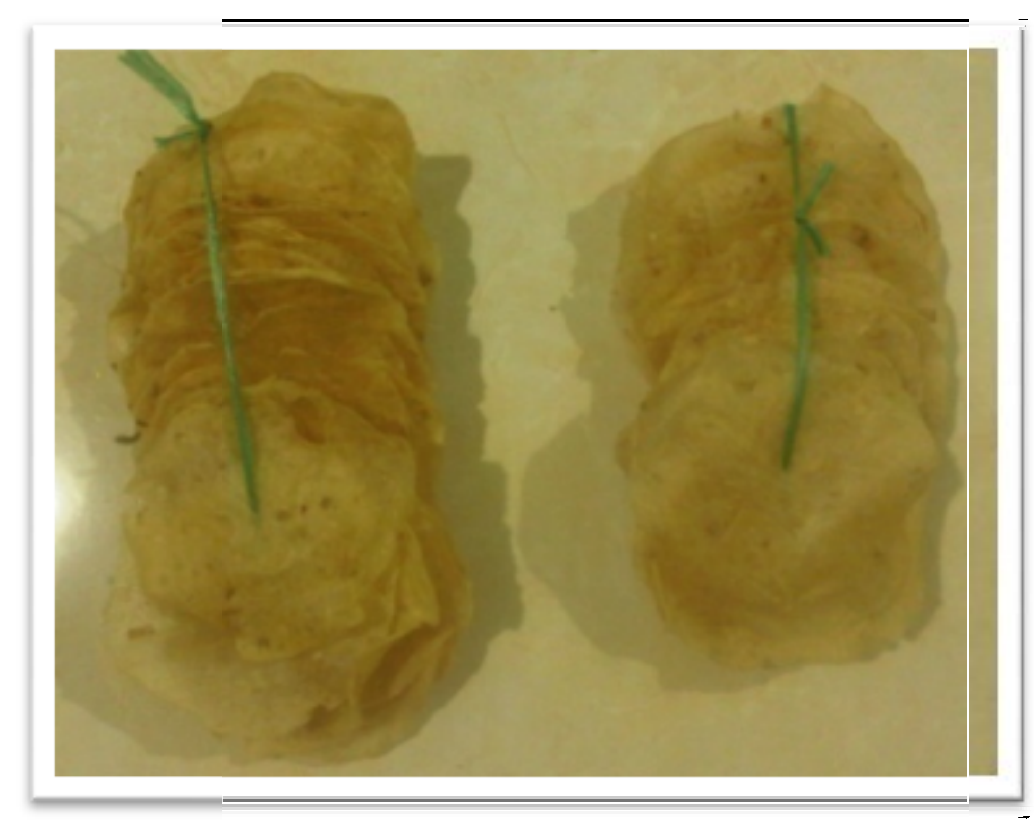

Gambar 4. Tampilan Produk Opak UD. Sugiono dan UD. Purwati Sebelum Modifikasi 


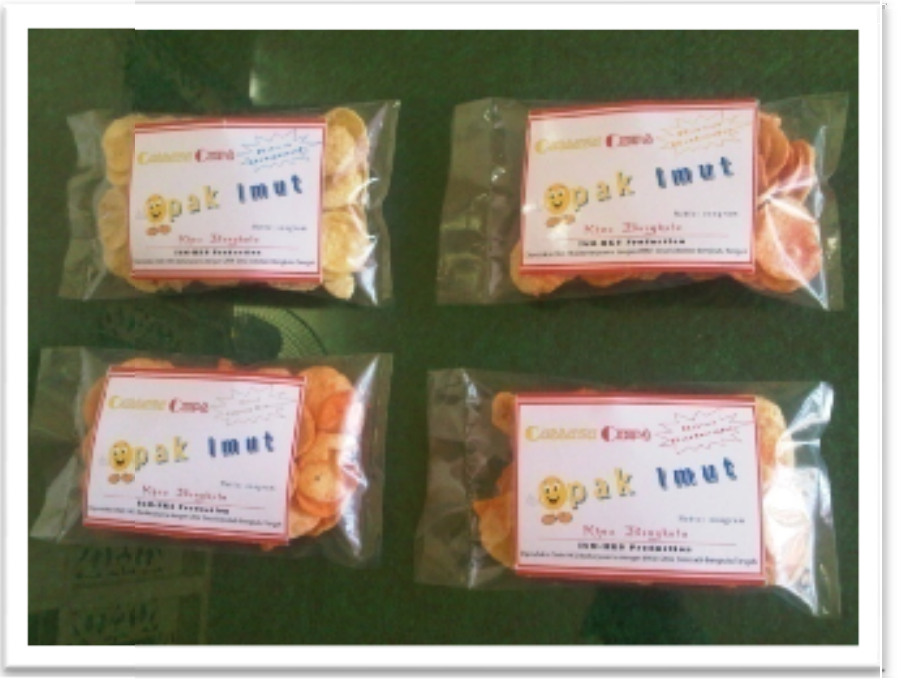

Gambar 5. Tampilan Produk “Cassava Chips” Merk Opak Imut UD Sugiono dan UD Purwati

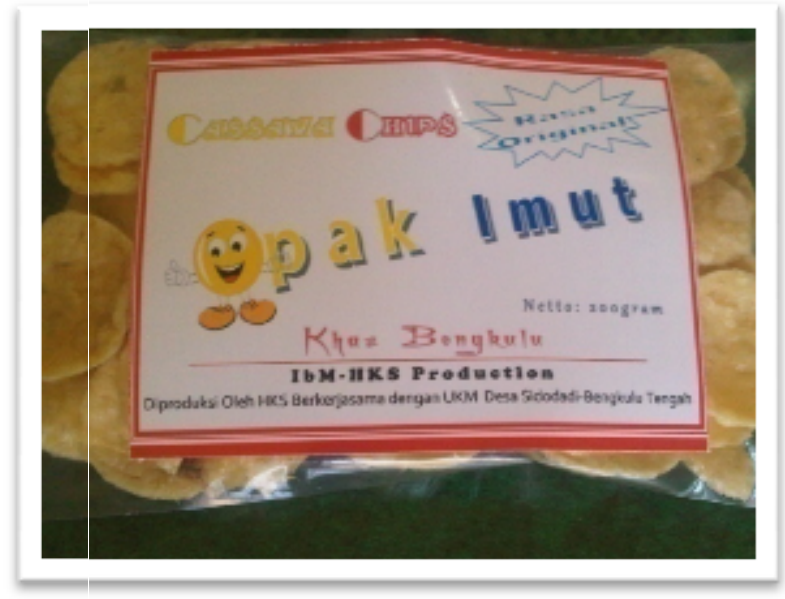

Gambar 6. Desain Kemasan "Cassava Chips” Merk Opak Imut

Mengingat arti penting kemasan pangan, perancangan desain kemasan juga mempunyai peranan yang tak kalah penting, sehingga tim beserta mitra membuat kesepakatan tentang desain kemasan yang efektif, efisien dan memberi daya tarik yang tinggi bagi konsumen.
Perancangan kemasan yang telah disepakati antara tim dengan mitra, dijelaskan sebagai berikut :

a. Bahan kemasan yang digunakan adalah kemasan plastik, terdiri dari 3 (tiga) variasi ukuran yaitu untuk berat opak 50 g (untuk konsumsi langsung) serta $250 \mathrm{~g}$ dan $500 \mathrm{~g}$ (untuk konsumsi keluarga ataupun oleh-oleh). 
b. Label kemasan berupa stiker yang didesain semenarik mungkin dengan nama merk dagang "Opak Imut" produksi UD. Sugiono dan UD. Purwati (desain kemasan ditampilkan pada Gambar 6).

c. Proses sealing dilakukan dengan menggunakan alat sealer mekanis.

\section{Perancangan Metode Pemasaran}

Dengan adanya perubahan dan modifikasi dari aspek teknologi pengolahan, diversifikasi varian rasa dan metode pengemasan, maka kegiatan pemasaran bisa lebih dikembangkan menuju areal yang lebih luas. Perbaikan metode pemasaran yang disepakati antara tim dan mitra adalah selain dengan cara menyajikan (display) di depan lokasi produksi, pemasaran opak yang telah diberi merk dagang "Opak Imut" ini dilakukan dengan menawarkan kepada distributor dan memasok ke warungwarung atau toko-toko di wilayah Kabupaten Bengkulu Tengah dan Kota Bengkulu. Ke depan, diharapkan jaringan pemasaran yang dicapai bisa menjadi lebih luas lagi.

\section{SIMPULAN}

Berdasarkan hasil kegiatan pengabdian kepada masyarakat yang telah dilaksanakan oleh tim, bekerjasam dengan mitra, bisa diambil kesimpulan bahwa :

a. Modifikasi teknologi pengolahan opak dengan metode pengecilan ukuran dan menambah varian rasa, bisa memperbaiki kualitas dan penerimaan konsumen terhadap produk opak yang diproduksi oleh UD. Purwati dan UD. Sugiono.

b. Tingkat penerimaan panelis yang dalam hal ini mewakili konsumen terhadap opak hasil modfikasi lebih tinggi dibandingkan dengan opak sebelum dilakukan modifikasi.

c. Hasil kesepakatan tim dengan mitra, desain kemasan yang digunakan untuk produk opak hasil modifikasi adalah dengan menggunakan kemasasan plastik ukuran berat produk $50 \mathrm{~g}, 250$ g dan $500 \mathrm{~g}$, dengan label bermerk dagang "Opak Imut".

d. Metode pemasaran yang digunakan adalah selain memajang di display juga dilakukan dengan cara menawarkan kepada distributor dan memasarkan langsung ke warung dan toko di wilayah Kota Bengkulu dan Kabupaten Bengkulu Tengah.

\section{UCAPAN TERIMAKASIH}

Ucapan terimakasih kami sampaikan kepada Ditlitabmas Kemenristek Dikti yang telah memberikan dana kegiatan pengabdian kepada masyarakat melalui 
Program Hibah Ipteks bagi Masyarakat

(IbM) untuk pendanaan Tahun 2015.

\section{DAFTAR PUSTAKA}

BPOM, 2011, Peraturan Kepala Badan Pengawas Obat dan Makanan RI No. HK.03.1.23.07.11.6664 Tahun 2011.

Effendi, S, 2009, Teknologi Pengolahan dan Pengawetan Pangan, Penerbit Alfabeta, Bandung.

Kartika,B, 2000, Pedoman Uji Inderawi, PAU Universitas Gadjah Mada, Yogyakarta.

Kotler Philip, Gary Armstrong, 2013, Prinsip-prinsip Pemasaran, Edisi 12, jilid 1 Penerbit Erlangga, Jakarta.

Kotler Phillip, Kevin Lane Keller, 2013, Manajemen Pemasaran, Edisi ke-13, jilid 1 Penerbit Erlangga, Jakarta.

Kusnandar, F, 2010., Pendugaan Umur Simpan Produk Pangan dengan Metode Accelerated Shelf-life Testing (ASLT), Seafast Center, IPB.

Profil Desa, 2014, Profil Desa Sidodadi Kecamatan Pondok Kelapa Kabupaten Bengkulu Tengah Bengkulu.

Robertson, G. L. (2013). "Food Packaging: Principles \& Practice". CRC Press.

Sakarruddin, 2011. Pemberdayaan Ekonomi Masyarakat Bersama LPTTG Malindo, LPTTG Malindo, Sulawesi Selatan.

Soekarto ST. 2006. Penilaian Organoleptik untuk Industri Pangan, Ebookpangan.com 